DOI: 10.5604/01.3001.0012.0707

\title{
ANALYSIS MEDICAL AND STEREOSCOPIC IMAGES BY E-MEDICUS SYSTEM
}

\author{
Tomasz Rymarczyk ${ }^{1,2}$ \\ ${ }^{1}$ Netrix S.A., Research and Development Center, ${ }^{2}$ University of Economics and Innovation in Lublin
}

Abstract. In this work, there were implemented methods to analyze and segmentation medical images by using different kind of algorithms. The solution shows the architecture of the system collecting and analyzing data. There was tried to develop an algorithm for level set method applied to piecewise constant image segmentation. These algorithms are needed to identify arbitrary number of phases for the segmentation problem. With the use of modern algorithms, it can obtain a quicker diagnosis and automatically marking areas of the interest region in medical images.

Keywords: segmentation, image analysis, level set method

\section{ANALIZA OBRAZÓW MEDYCZNYCH I STEREOSKOPOWYCH W SYSTEMIE E-MEDICUS}

Streszczenie. W pracy zaimplementowano metody analizy i segmentacji obrazów medycznych przy użyciu różnych algorytmów. Rozwiąanie pokazuje architekturę systemu zbierającego $i$ analizujacego dane. Podjęto próbę opracowania algorytmu dla metody zbiorów poziomicowych stosowanej do fragmentarycznej, stałej segmentacji obrazu. Metody te sa potrzebne do identyfikacji dowolnej liczby faz dla problemu segmentacji. Dzięki zastosowaniu nowoczesnych algorytmów można uzyskać szybszą diagnozę $i$ automatyczne oznaczanie obszarów w regionach zainteresowania w obrazach medycznych.

Słowa kluczowe: segmentacja, analiza obrazów, metoda zbiorów poziomicowych

\section{Introduction}

In medical clinical research and practice, imaging has become an essential part to diagnose and to study anatomy and function of the human body. The image data is of immense practical importance in medical informatics. Medical images, such as Computed Axial Tomography (CAT), Magnetic Resonance Imaging (MRI), Ultrasound, and X-Ray, in standard DICOM formats are often stored in Picture Archiving and Communication Systems (PACS) and linked with other clinical information in EHR clinical management systems. Research efforts have been devoted to processing and analyzing medical images to extract meaningful information such as volume, shape, motion of organs, to detect abnormalities, and to quantify changes in follow-up studies.

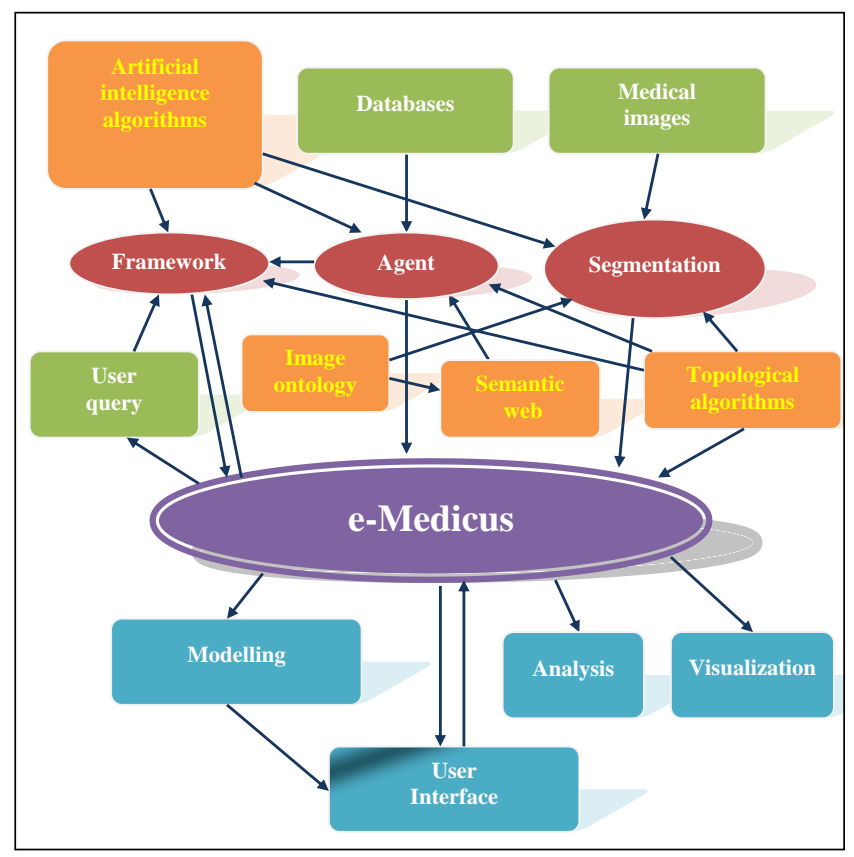

Fig. 1. The architecture of the e-Medicus system

Recent advances in a wide range of medical imaging technologies have revolutionized how we view functional and pathological events in the body and define anatomical structures in which these events take place. X-ray, CAT, MRI, Ultrasound, nuclear medicine, among other medical imaging technologies, enable $2 \mathrm{D}$ or tomographic 3D images to capture in-vivo structural and functional information inside the body for diagnosis, prognosis, treatment planning and other purposes. The architecture of such the medical system was projected in the Figure 1.

The e-Medicus system consists:

- artificial intelligence algorithms,

- segmentation algorithms

- the framework,

- agents,

- topological algorithms,

- databases,

- visualization systems,

- the user interface.

\section{Segmentation}

The image segmentation refers to the process of partitioning a digital image into multiple regions. There is typically used to locate objects and boundaries in images. The level set method is a powerful tool for representing moving or stationary interfaces. There was used the idea of the variational formulation for geometric active contours. There was used to minimization problem in image processing to compute piecewise-smooth optimal approximations of the given image. The proposed algorithm has been applied to real pictures with promising results in the image segmentation [12-18].

The level set method tracks the motion of an interface by embedding the interface as the zero level set of the signed distance function. The motion of the interface is matched with the zero level set, and the resulting initial value partial differential equation for the evolution of the level set function. The idea is merely to define a smooth function $\phi(x, t)$, that represents the interface as the set where $\phi(x, t)=0$. The motion is analyzed by the convection the $\phi$ values (levels) with the velocity field.

For more than two phases was introduced the multiple level sets idea by Vese and Chan. The algorithm set formulation and algorithm for the general Mumford-Shah minimization problem in image processing, to compute piecewise-smooth optimal approximations of a given image [10-11, 21].

The problem can be easily generalized to the case where the domain contains more than two materials.

$$
F(s, C)=\omega \boldsymbol{L}(C)+\eta \int_{\Omega}\left(\mathrm{s}_{\mathrm{o}}-\mathrm{s}\right)^{2} \mathrm{~d} \Omega+\iint_{\Omega \backslash \mathrm{C}}|\nabla \mathrm{s}|^{2} \mathrm{~d} \Omega
$$


The process for minimization of the functional is the following:

$$
\frac{\partial \phi}{\partial t}=\delta_{\varepsilon}(\phi)\left[\omega \nabla \cdot\left(\frac{\nabla \phi}{|\nabla \phi|}\right)-\eta_{1}\left(\mathrm{~s}_{\mathrm{o}}-\mathrm{c}_{1}\right)^{2}+\eta_{2}\left(\mathrm{~s}_{\mathrm{o}}-\mathrm{c}_{2}\right)^{2}\right]
$$

where coefficients $c_{1} i c_{2}$ are mean values of points in the picture.

The formulation of the variational level set method consists of an internal energy term that penalizes the deviation of the level set function and an external energy term that drives the motion of the zero level set toward the desired image features. When flat or steep regions complicate the determination of the contour, the reinitialization is necessary. This reinitialization procedure is based by replacing by another function that has the same zero level set but behaves better. Variational formulation for geometric active contours that forces the level set function to be close to a signed distance function, and therefore completely eliminates the need of the costly reinitialization procedure.

The resulting evolution of the level set function is the gradient flow that minimizes the overall energy functional:

$$
\boldsymbol{P}(\phi)=\int_{\Omega} \frac{1}{2}(|\nabla \phi|-1)^{2} \mathrm{~d} x \mathrm{~d} y
$$

An external energy for a function $\phi(\mathrm{x}, \mathrm{y})$ is defined as below:

$$
\boldsymbol{E}(\phi)=\mu \boldsymbol{P}(\phi)+\boldsymbol{E}_{m}(\phi)
$$

where:

$\boldsymbol{P}(\phi)$ - internal energy, $\boldsymbol{E}_{m}(\boldsymbol{\phi})$ - external energy.

Denoting by $\frac{\partial \mathbf{E}}{\partial \phi}$ the Gateaux derivative of the functional $\mathbf{E}$ receiving the following evolution equation:

$$
\frac{\partial \phi}{\partial t}=-\frac{\partial \mathbf{E}}{\partial \phi}
$$

In the image segmentation active contours are dynamic curves that moves towards the object boundaries. Denoting letter $I$ as an image, and $g$ be the edge indicator function defined by:

$$
g=\frac{1}{1+\left|\nabla G_{\sigma} * I\right|^{2}}
$$

where $G_{\sigma}$ is the Gaussian kernel with standard deviation $\sigma$.

The process for minimization of the functional $\boldsymbol{E}$ is the following:

$$
\frac{\partial \phi}{\partial t}=\mu\left[\Delta \phi-\operatorname{div}\left(\frac{\nabla \phi}{|\nabla \phi|}\right)\right]+\lambda \delta(\phi) \operatorname{div}\left(g \frac{\nabla \phi}{|\nabla \phi|}\right)+\omega g \delta(\phi)
$$

The formulation of the variational level set method with Mumford-Shah model is following:

$$
\begin{aligned}
& F\left(\phi, \mathrm{c}_{1}, \mathrm{c}_{2}\right)=\int_{\Omega} \frac{1}{2}(|\nabla \phi|-1)^{2} \mathrm{~d} x \mathrm{~d} y+\omega \int_{\Omega}|\nabla \mathrm{H}(\phi)| \mathrm{d} \Omega \\
& +\lambda_{1} \int_{\Omega}\left(\mathrm{u}_{\mathrm{o}}-\mathrm{c}_{1}\right)^{2} \mathrm{H}(\phi) \mathrm{d} \Omega+\lambda_{2} \int_{\Omega}\left(\mathrm{u}_{\mathrm{o}}-\mathrm{c}_{2}\right)^{2}(1-\mathrm{H}(\phi)) \mathrm{d} \Omega
\end{aligned}
$$

\section{E-Medicus System}

E-Medicus system consists artificial intelligence algorithms, segmentation algorithms, framework, agents, topological algorithms, databases, visualization systems and user interface.

Medical image segmentation, which aims at automated extraction of object boundary features, plays a fundamental role in understanding image content for searching and mining in medical image archives. A challenging problem is to segment regions with boundary insufficiencies, i.e., missing edges and/or lack of texture contrast between regions of interest (ROIs) and background. Lately, much interest has been raised in the medical imaging community about segmentation algorithms that use active contours or surfaces. In e-Medicus use segmentation algorithms such as natural and generic networks, algorithm Beyesa, level set method, fuzzy sets and algorithm k-means (Fig. 2). The algorithms used allow to segment all pathological changes in the image.
Through continuous improvement of algorithms, we come to reduce the noise in the medical image (Fig. 3) [4-9, 19].

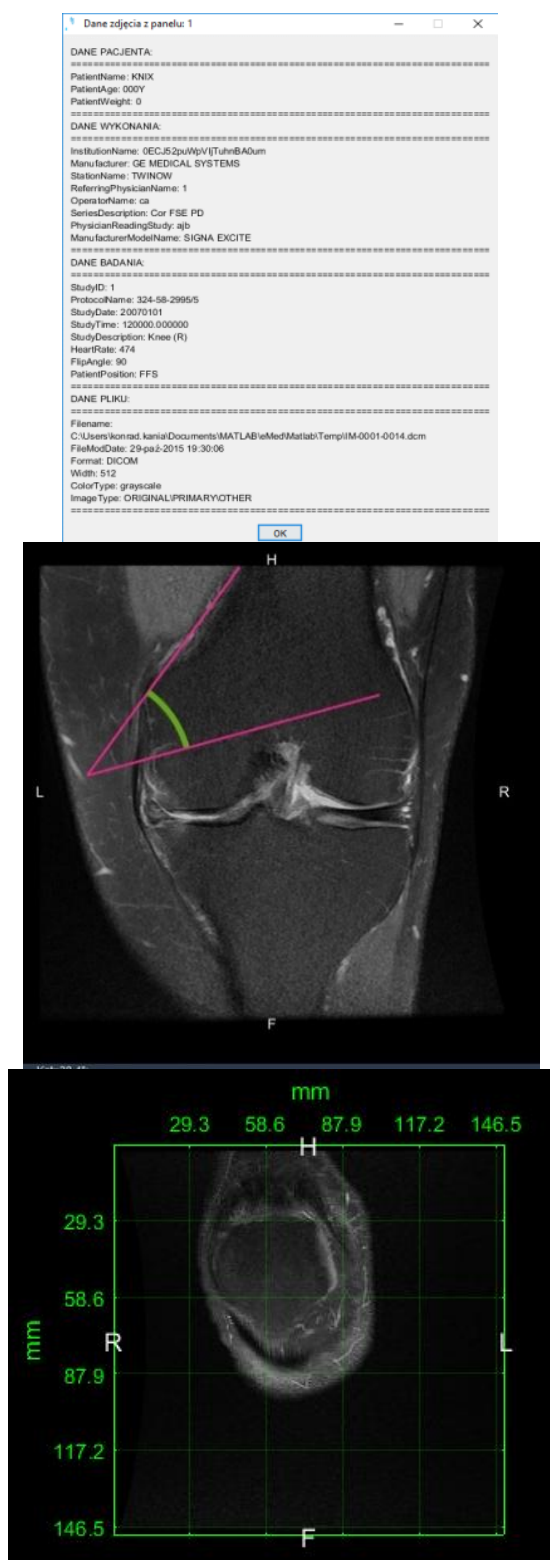

Fig. 2. Examples in e-Medicus system

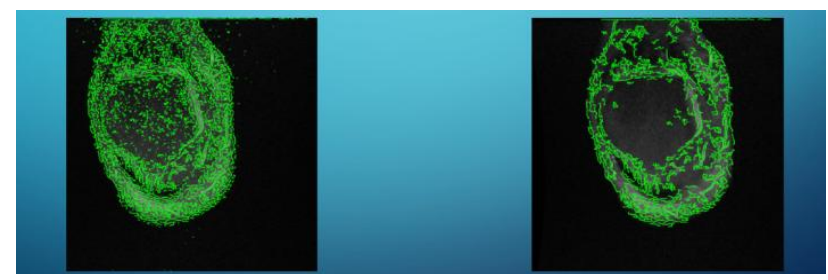

Fig. 3. On the right binarization without filtering, on the left binarization in filtering

\section{System for the acquisition of stereoscopic images of skin lesions}

Stereoscopic imaging techniques allow for 3D images. Simultaneous recording of two images allows for the mutual dependence of the spatial object, the distance from the observer and the depth of the scene. In order to obtain stereoscopic images a pair of two-dimensional images (stereoparas) representing a subject or scene from two points of view are made. Stereo image compositions are very similar, but they vary slightly in the way they look at objects and in the details of each object's crossing in the scene. It is these tiny differences that carry information about the third dimension. The stereoscopic skin lesion acquisition and analysis system consists of a dedicated recording device 
and a computer aided image analysis program e-Medicus. The unit consists of two camera modules $(101,102)$, a multiadaptera camera (100), a microprocessor controller (105), an lighting unit (103) and a power supply (104). The stereoscopic image is obtained by recording the image on one and the other camera. Cameras are set at a fixed distance $(\mathrm{D}=35 \mathrm{~mm})$ from each other. This distance is determined between the main optical axes of the camera lenses. Illumination of skin lesions during shooting is accomplished through a set of LED spots (103). Illuminated dots are digitally digitally controlled eight-digit RGB LEDs. Each point can have individually set parameters such as the intensity and colour of the emitted light wave. The microprocessor controller (105) controls the multiadapter camera (100) for proper operation of the acquisition and illumination system. The connection of the cameras to the adapter is made using a flexible (flexible) tape consisting of fifteen communication wires. Figure 4 presents the device for stereoscopic images of skin lesions. Calibration and test reconstructions of stereoscopic photographs was shown in Fig. 5 and 6.

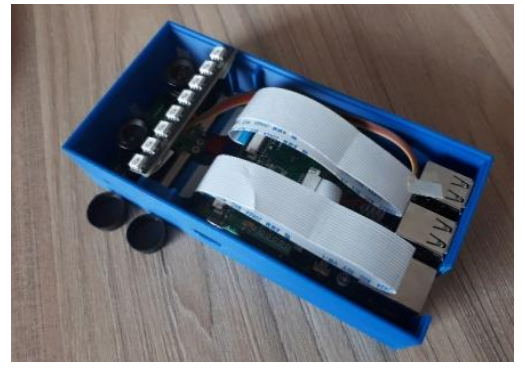

Fig. 4. Device for stereoscopic images of skin lesions

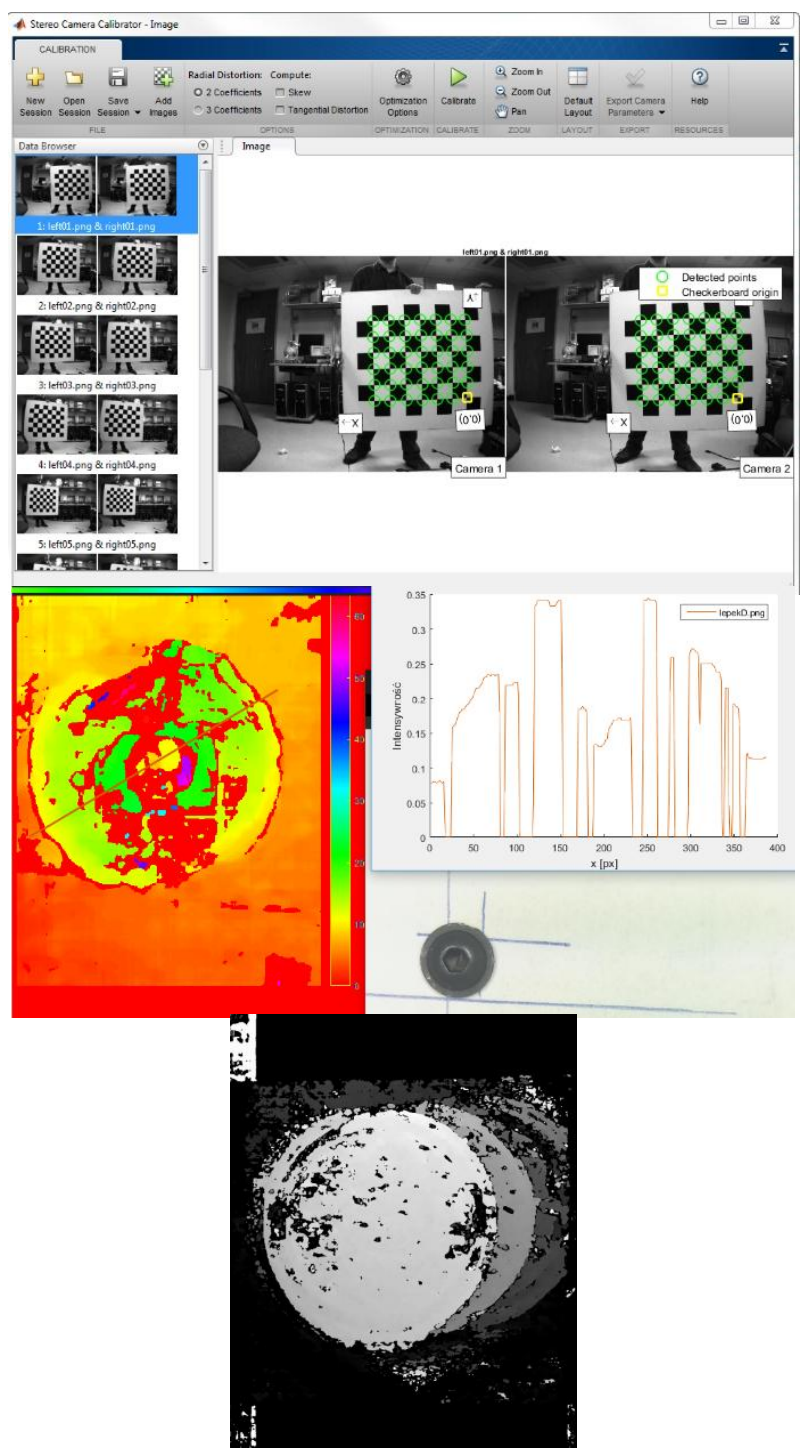

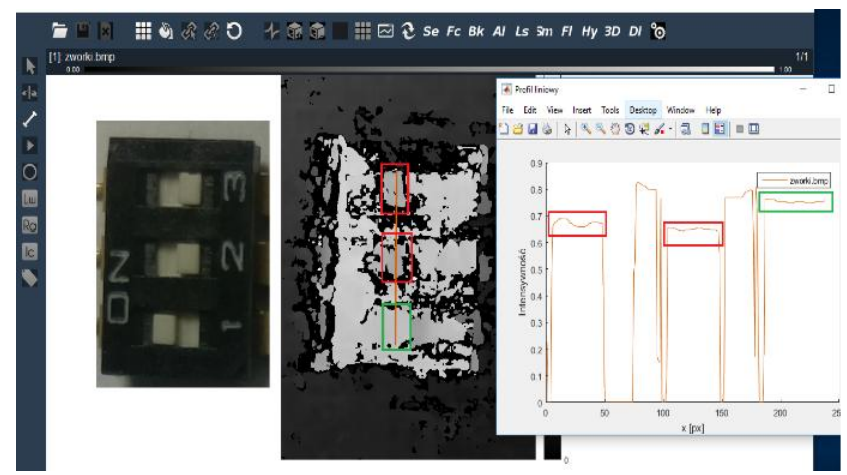

Fig. 6. Test reconstructions of stereoscopic photographs

The microprocessor controller is also responsible for communication between the recording device and a computer (109) equipped with dedicated e-Medicus software, implemented in Ethernet (108). Control of the device for image acquisition and lighting is done by dedicated e-Medicus (110) computer program. At the same time, the application allows for the qualitative analysis of stereoscopic 3D images of skin lesions, including cancerous ones.

The first step of skin surface should be identification of the lesion as melanocytic or non-melanocytic [1-3, 20]. In case of the identification of the melanocytic lesion next step should be classification as benign, malignant or "suspicious" (Fig. 7). Currently the most commonly used method for screening and the fast evaluation of the melanocytic lesions is $\mathrm{ABCD}$ rule, which according to Nachbar showed $92 \%$ specificity, 91\% sensitivity and $80 \%$ of diagnostic accuracy in evaluation of malignant melanoma. It bases on evaluation of lesion in 4 aspects: A - Asymmetry, B - Borders, C - Colours, and D - Differential structures (Tab. 1). Figures 8 presents the image segmentation by using the level set algorithm (the pigmented skin lesions).

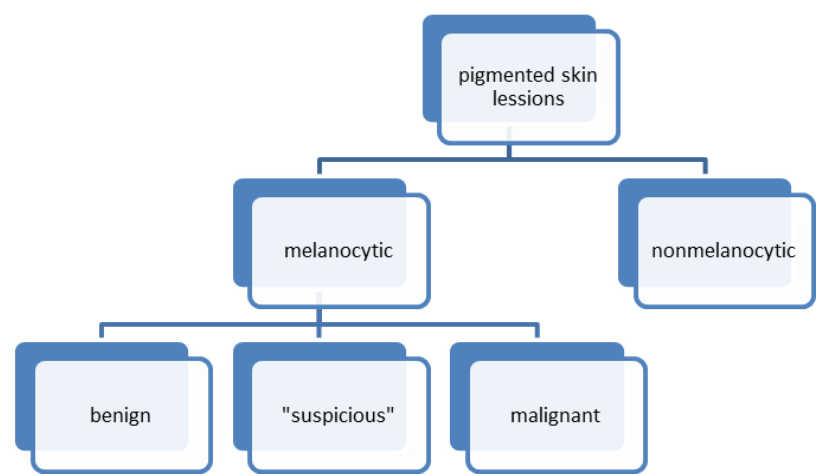

Fig. 7. The two-step procedure for the classification of pigmented skin lesions
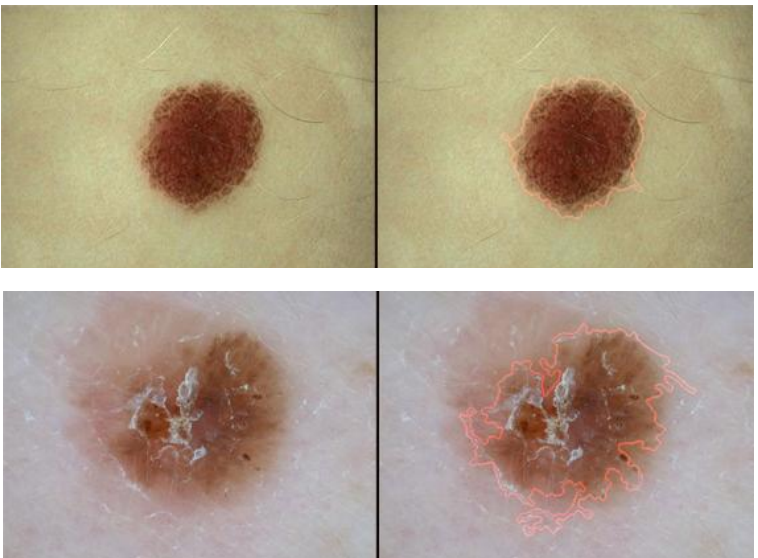

Fig. 8. The medical image analysis by Level Set Method (looking for areas with specific characteristics) 
Table 1. ABCD rule parameters description

\begin{tabular}{|c|c|c|c|c|}
\hline \multicolumn{2}{|r|}{ Parameter } & Description & Values & TDS weight factor \\
\hline A & Assymetry & Complete symmetry, asymmetry in 1 or 2 axis & $0-2$ & 1,3 \\
\hline B & Borders & $\begin{array}{l}8 \text { segments, } 1 \text { point for abrupt cut-off of } \\
\text { pigment }\end{array}$ & $0-8$ & 0,1 \\
\hline c & Colours & $\begin{array}{l}1 \text { point for each color: white, red, light brown, } \\
\text { dark brown, black, blue-gray }\end{array}$ & $1-6$ & 0,5 \\
\hline D & $\begin{array}{l}\text { Differential } \\
\text { structures }\end{array}$ & $\begin{array}{l}1 \text { point for every structure: } \\
\text { pigment network, structureless areas, dots, } \\
\text { globules, streaks }\end{array}$ & $1-5$ & 0,5 \\
\hline
\end{tabular}

\section{Processing and analysis of medical images}

Processing and analysis of medical images using computer comprises the following: image formation and reconstruction image restoration, image enhancement, image compression and storage, image-based visualization, feature identification, image segmentation, shape recognition, image matching/registration, and measurement of anatomical and physiological parameters. Using an algorithm level set method and the determination of the relevant parameters, there was achieved the following results (Fig. 9).

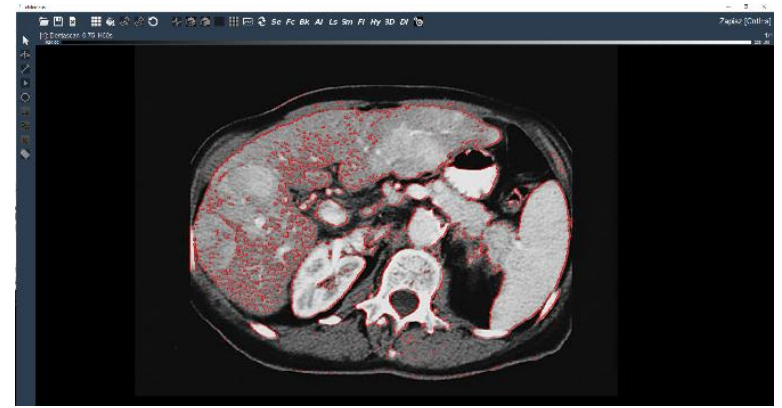

Fig. 9. Segmentation by Level Set Method
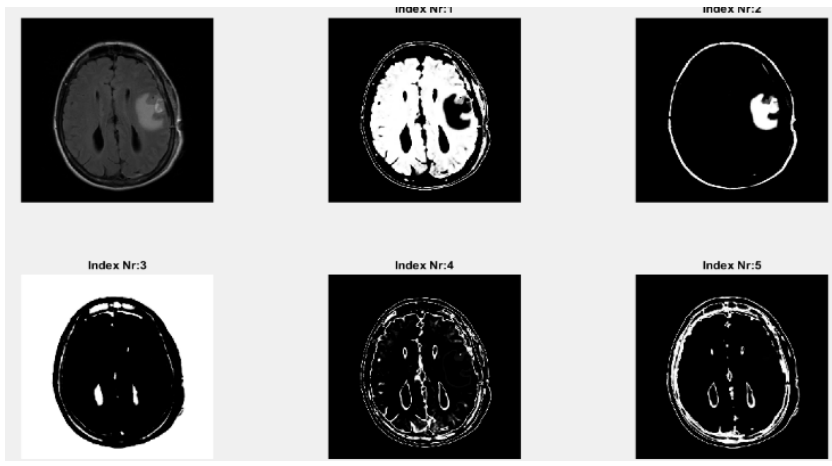

Fig. 10. Fuzzy sets

After setting the appropriate parameters, the algorithm is able to obtain satisfactory results for us. Mark not only interesting object but also the outline of the whole picture. The best algorithm that has highlighted exactly the area of interest is the Fuzzy sets (Fig. 10). As you can see in the pictures above, by indexing the medical image, the algorithm detects the appropriate scale of grays and on this basis correctly marks the object of interest, in this case changed in the brain.

\section{Conclusion}

In medical clinical research and practice, imaging has become an essential part to diagnose and to study anatomy and function of the human body. The proposed algorithms have been used to real pictures with promising results in the medical images segmentation. With the use of modern algorithms, the physician is able to obtain a quicker diagnosis. By automatically marking areas of interest you will notice all the changes in medical images. This will allow artificial intelligence to automatically diagnose changes and to tell the radiologist what type of disease is present in the medical image. In this work, there were developed and effective algorithms and the e-Medicus system to machine learning, analysis and compare medical images.

\section{References}

[1] Argenziano G., Soyer P.H., De Giorgi V., Piccolo D.: Interactive atlas of dermatoscopy, EDRA 2000.

[2] Balla-Arabe S., Gao X.: A Fast and Robust Level Set Method for Image Segmentation Using Fuzzy Clustering and Lattice Boltzmann Method. IEEE Trans Cybern. 43(3), 2013.

[3] Braun R.P., Rabinovitz H.S.: Dermoscopy of pigmented skin lesions. J. Am. Acad. Dermatol. 52, 2005, 109-121.

[4] Gdula A., Rymarczyk T.: Application Computational Algorithms for Analysis of Dental Image. Proc. of WD 2015

[5] Jajuga K.: Statystyczna teoria rozpoznawania obrazów. PWN. Warszawa 1990.

[6] Johr R.H.: Dermoscopy: Alternative melanocytic algorithms-the ABCD rule of dermatoscopy, Menzies scoring method, and 7-point checklist. Clin Dermatol. 20(3), 2002, 240-247.

[7] Kamińska J., Winciorek G.: Dermatologia cyfrowa. Cornetis. Wrocław 2008.

[8] Kurzyński M.: Rozpoznawanie obiektów. Metody statystyczne. Oficyna Wydawnicza Politechniki Wrocławskiej. Wrocław 1997.

[9] Li C., Kao C., Gore J. C., Ding Z.: Minimization of Region-Scalable Fitting Energy for Image Segmentation. IEEE Trans. Image Processing 17 (10), 2008, 1940-1949.

[10] Mumford D., Shah J.: Optimal approximation by piecewise smooth functions and associated variational problems. Communications on Pure and Applied Mathematics 42(5), 1989, 577-685 [DOI: 10.1002/cpa.3160420503].

[11] Osher S., Fedkiw R.: Level Set Methods and Dynamic Implicit Surfaces. Springer. New York 2003

[12] Osher S., Sethian J.A.: Fronts Propagating with Curvature Dependent Speed: Algorithms Based on Hamilton-Jacobi Formulations. Journal of Computational Physics 79, 1988, 12-49.

[13] Ossowski S.: Sieci neuronowe do przetwarzania informacji. Politechnika Warszawska. Warszawa 2006

[14] Osowski S., Markiewicz T., Kruk M., Kozłowski W.: Metody sztucznej inteligencji do wspomagania diagnostyki patologii tkanek. WAT. Warszawa 2011.

[15] Rymarczyk T.: Characterization of the shape of unknown objects by inverse numerical methods. Przegląd Elektrotechniczny 7b/2012, 138-140,

[16] Rymarczyk T., Osior K.: E-Medicus System for Analysis and Images Segmentation. Proc. of. IIPhWD 2013.

[17] Rymarczyk T., Filipowicz S.F., Sikora J., Polakowski K.: A piecewise-constant minimal partition problem in the image reconstruction. Przegląd Elektrotechniczny 12/2009, 141-143.

[18] Sethian J.A.: Level Set Methods and Fast Marching Methods. Cambridge University Press, 1999.

[19] Stapor K.: Metody klasyfikacji obiektów w wizji komputerowej. Wydawnictwo Naukowe PWN. Warszawa 2011.

[20] Stolz W., Braun-Falco O.: Color atlas of dermatoscopy. Blackwell Science, 1994.

[21] Vese L. Chan T.: A new multiphase level set framework for image segmentation via the Mumford and Shah model. CAM Report 01-25, UCLA Math. Dept., 2001.

\section{Acknowledgments}

Projekt współfinansowany przez Unię Europejską z Europejskiego Funduszu Regionalnego. Działanie 1.4 - wsparcie projektów celowych. Umowa nr UDA-POIG.01.04.00-06-022/11-00. Nazwa Beneficjenta - Netrix S.A. dawniej Net-Art Paweł Rymarczyk. Tytuł projektu „Stworzenie prototypu aplikacji e-Medicus opartej na funkcjach zbiorów poziomicowych oraz algorytmach inteligencji obliczeniowej" (2012-2015).

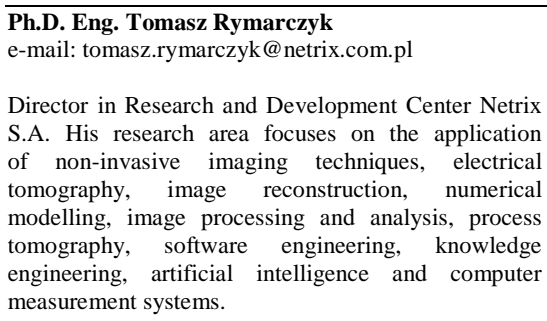

Director in Research and Development Center Netrix S.A. His research area focuses on the application of non-invasive imaging techniques, electrical tomography, image reconstruction, numerical modelling, image processing and analysis, process tomography, software engineering, knowledge engineering, artificial intelligence and computer measurement systems.

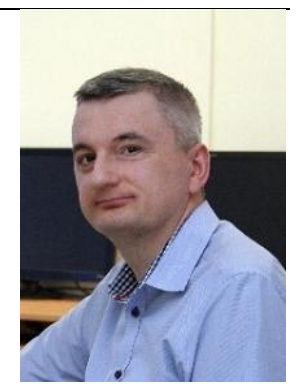

otrzymano/received: 02.03.2018 przyjęto do druku/accepted: 11.05 .2018 